Florida International University FIU Digital Commons

1979

\title{
A proposal to partially decentralize food purchasing within one major unit of Florida Health and Rehabilitation Services
}

Martin Joseph Casola

Florida International University

DOI: $10.25148 /$ etd.FI14052599

Follow this and additional works at: https://digitalcommons.fiu.edu/etd

\section{Recommended Citation}

Casola, Martin Joseph, "A proposal to partially decentralize food purchasing within one major unit of Florida Health and Rehabilitation Services" (1979). FIU Electronic Theses and Dissertations. 2065.

https://digitalcommons.fiu.edu/etd/2065 
Dear Mr. Casola:

Florida International University's Digital Collections Center is offering a new service to graduate alumni: digitization of your theses and dissertations. This new service will enable your scholarship to be preserved and shared for research and educational purposes, at no cost to you, and will be made available through FIU's Electronic Theses and Dissertations on our Digital Commons website. The FIU Digital Commons is a digital repository for capturing, archiving and disseminating the research, creative and scholarly output of the Florida International University community. Our graduates' theses and dissertations are a valuable part of FIU's scholarship, and are a frequently accessed part of our digital collections.

Your 1979 thesis titled A proposal to partially decentralize food purchasing within one major unit of Florida Health and Rehabilitation Services is in the process of being digitized for preservation and so that it may be made available in Digital Commons. At your earliest convenience, please reply to this email providing your authorization for your thesis to be made available online. Please be advised that FIU may make your thesis available online if we do not hear back from you within 90 days. If at any point you wish to have your thesis taken offline, please contact us at dcc@fiu.edu and we will be happy to do so. To accommodate needs such as publishing contracts and patents, FIU can also add a period of embargo, or alternatively provide only an excerpt of your thesis.

If you have any questions or concerns, please do not hesitate to contact me. Thank you for your contributions to Florida International University!

Sincerely,

Rebecca Bakker

Digital Project Coordinator

Digital Collections Center

Green Library - GL 825, MMC Campus

Florida International University

Reference \# FI14052599 